REGIONAL ANDSECTORAL EFFECTS OFA COMMON MONETARY POLICY: EVIDENCE FROM EURO REFERENDA IN DENMARK AND SWEDEN

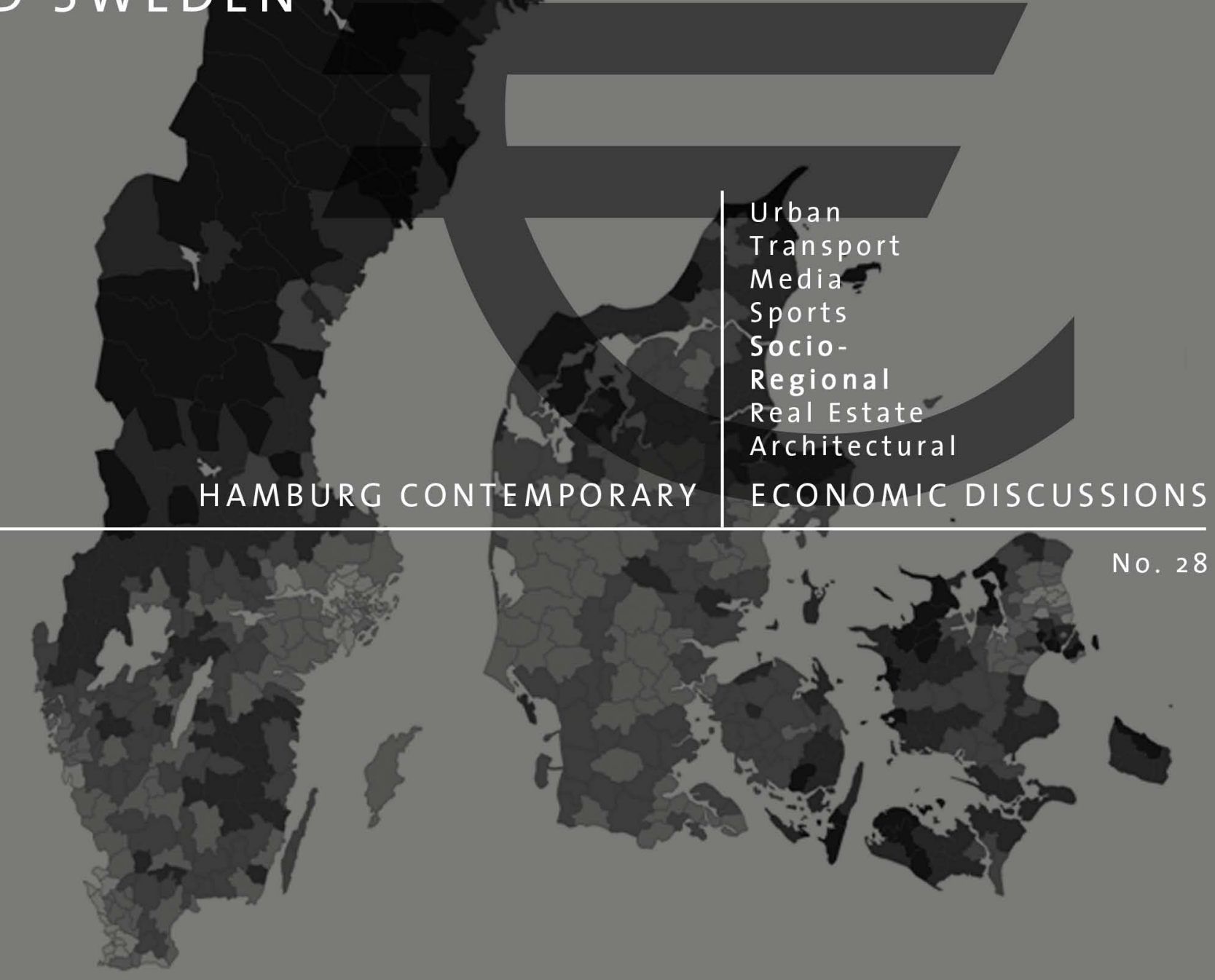


Hamburg Contemporary Economic Discussions

University of Hamburg Faculty Economics and Social Science

Chair for Economic Policy

Von-Melle-Park 5

D-20146 Hamburg | Germany

Tel $+494042838-4622$

$\mathrm{Fax}+494042838-6251$

http://www.uni-hamburg.de/economicpolicy/

Editor: Wolfgang Maennig

P. Gabriel M. Ahlfeldt

University of Hamburg

Faculty Economics and Social Science

Chair for Economic Policy

Von-Melle-Park 5

D-20146 Hamburg | Germany

Tel $+494042838-5569$

Fax $+494042838-6251$

ahlfeldt@econ.uni-hamburg.de

Wolfgang Maennig

University of Hamburg

Faculty Economics and Social Science

Chair for Economic Policy

Von-Melle-Park 5

D-20146 Hamburg | Germany

Tel $+494042838-4622$

Fax $+494042838-6251$

maennig@econ.uni-hamburg.de

Tobias Osterheider

University of Hamburg

Faculty Economics and Social Science

ISSN 1865 - 2441 (Print)

ISSN 1865 - 7133 (Online)

ISBN 978 - 3 - $940369-70$ - 3 (Print)

ISBN 978 - 3 - 940369 - 71 - o (Online) 


\title{
Regional and Sectoral Effects of a Common Monetary Policy: Evidence from Euro Referenda in Denmark and Sweden
}

\begin{abstract}
This article provides empirical evidence for the (anticipated) net costs and benefits of a common monetary policy that varies across regions depending on the industry mix. The paper is the first to approach the issue of the regional and sectoral effects of a common monetary policy by using empirical spatial models to analyze referenda. Here, the referenda examined are the 2000 and 2003 referenda held in Denmark and Sweden regarding participation in the EMU. We find that voters in regions with a high proportion of interest-sensitive sectors and low international integration tend to oppose participation in a currency union. The opposite is true for non-interest-sensitive sectors with relatively high integration. These findings are in line with the hypothesis of rational voters maximizing utility. Furthermore, perceived net costs are found to increase with distance from the European core and with the age of voters, indicating that a national currency represents an experience good. These results are robust to spatial dependencies and are not driven by broader forms of Euro-skepticism.

Keywords: EMU, Euro, Regional \& Sectoral Effects of Monetary Policy, Public Referenda, Denmark, Sweden JEL classification: E52, P16, R12
\end{abstract}

Version: October 2009

\section{Introduction}

A common monetary policy within competitive markets may hardly target regional particularities and requirements (CRONE, 2007). However, there is a regionally heterogeneous transmission of a common monetary policy, and this heterogeneity is most likely attributable to regional differences in the industry mix (CARLINO \& DEFINA, 1998, 1999). VAR models have shown that distinct sectors react differently to monetary shocks. Accordingly, interest-sensitive sectors that rely heavily on foreign capital are adversely affected by a monetary policy that is oriented to the average needs of a common market. Understanding the regional dimension of monetary policies is crucial, particularly within heterogeneous currency areas such as the European Monetary Union (EMU), as it helps to build ex- 
pectations on how scheduled monetary policy interventions will affect different regions, if not to target regional particularities.

We approach the regional dimension of a common monetary policy from a new perspective by investigating the 2000 and 2003 public referenda held in Denmark and Sweden regarding participation in the EMU as well as the 1994 Swedish referendum on participation in the EU in a spatial analysis. Assuming rational voters, we expect a high proportion of voters working within interest-sensitive sectors to show increased local opposition to the EMU in the referenda.

We go beyond the scope of the existing literature on the regional and sectoral effects of monetary policy by considering relative benefits that vary across sectors and regions depending on the integration within the currency union. As a result of both influences, regions with a strong presence of industries with low integration and high interest sensitivity should exhibit a relatively large proportion of votes against the EMU, while the opposite should be true in regions where industries with high integration and relatively low interest sensitivity are concentrated. We provide evidence on a range of further determinants of regional opposition to the EMU, identifying influencing factors such as remoteness to European and national economic cores, urbanity, average age, rate of unemployment and support of political parties that oppose the Euro. While the impact of the key sectors of interest was found to be robust and consistent across countries, the other influencing factors partly varied between countries.

These findings are of particular relevance, as the current global financial crisis has reintroduced the question of EMU membership. In Denmark, a second referendum will be held prior to the next elections in 2011. In Sweden, the topic is a central issue of the 2010 election. 


\section{Regional Effects of Monetary Policy}

\subsection{Optimum Currency Area Theory and Regional Effects of Monetary Policy}

Following the Maastricht treaty, the EMU became effective on the January 1, 1999. Whether a single currency for a broad set of European countries could be appropriate has been heavily discussed at least since the treaty was signed in 1992. However, the scholarly debate about the efficiency of currency unions in general has a much deeper tradition. Clearly, currency unions may reduce transaction costs of trade with partner economies and reduce the risk associated with transnational investment, although critics sometimes argue that these benefits are negligible (CALMFORS et al., 1997; FELDSTEIN, 1997). However, these benefits come at the expense of giving up an independent national monetary and exchange rate policy. The related cost can be negligible if the criteria of optimum currency areas (OCA) apply (MUNDELL, 1961).

The 'homogeneity of countries' has emerged as the 'catch all' OCA property (MONGELLI, 2002); if countries all face the same common shocks, a common monetary policy will be appropriate (FELDSTEIN, 1997). The empirical literature, however, has quite clearly rejected homogeneity for European countries, e.g., by analyzing business cycles. Although some studies find significant correlations between business cycles for a core of European countries, regional supply and demand shocks and response functions are substantially less correlated than those between U.S. states (BAYOUMI \& EICHENGREEN, 1993, 1996). Also, labor mobility within European countries is relatively small compared to that within the US (OBSTFELD \& PERI, 1998). Finally, Sachs and Sala-I-Martin (1992) estimate for the U.S. economy that regional redistribution schemes offset 40 percent of the fall in a state's GDP, due to a reduction in tax transfers to the federal government and increased transfer receipts. No similar fiscal transfer mechanisms, however, are available in Europe.

Denmark and especially Sweden (in addition to Portugal, the UK and Ireland) do not belong to the European core states (ARTIS \& ZHANG, 2002; KOUPARITSAS, 
1999). If anything, Sweden exhibits more similarities with the other "outs" Denmark and the UK (JANSSON, 1997), Obviously, the 'Lucas Critique' may apply in the case of the EMU. Inferences based on the results of historical analyses might be misleading if the event of the EMU changes the underlying economic fundamentals (FRANKEL \& ROSE, 1997). Indeed, there is evidence that increased trade within a currency union leads to a reduction in economic heterogeneity (DE GRAUWE, 2007). Nevertheless, it seems fairly justified to state that by the time of the referenda in Denmark (2000) and Sweden (2003), the EMU did not represent an OCA for both countries and that there would have been substantial costs associated with joining the EMU, which is one of the key essences we need as a background for our analyses.

The second issue, which is essential in the context of our analysis, is that monetary policies trigger not only distinct reactions across member states of currency unions but also different reactions within regions of single countries. Recent research suggests that heterogeneity between regions of a single country may be as influential as differences across countries. It is, therefore, easier to identify a set of European core regions than core countries (FORNI \& REICHLIN, 1997, 2001). This is because almost all traditional core countries show some regions that do not comply with core group characteristics, while non-core countries contain important regions that behave synchronously with the European core. This phenomenon is gaining in strength as correlations between regions within single countries have been decreasing over time, while cross-country correlations between regions of different countries have increased (FATAS, 1997). However, most of the research on the perception of monetary policies still focuses on a national scale (DOW \& RODRÍGUEZ-FUENTES, 2003). As an exception, CARLINO \& DEFINA (1999) identify on the basis of structural VAR models considerable differences across U.S. regions in the economic perception of common monetary shocks. Sectoral differences in interest rate sensitivity provide a straightforward explanation for these distinct reactions (CRONE, 2007). By setting short-term interest rates, central banks influence the cost of capital and thus spending on durable goods such as fixed investment, housing, inventories and consumer durables (transmission via 
the money channel). CARLINO \& DEFINA (1998) conclude that the construction and manufacturing of durable goods have historically been very sensitive to changes in interest rates. These findings are supported by a number of similar studies conducted on a national scale (BERNANKE \& GERTLER, 1995; DORNBUSCH, FAVERO, \& GIAVAZZI, 1998). Alternative explanations referring to regional heterogeneity in firm size and bank size, which theoretically affect the transmission of monetary policies over the credit channel (KASHYAP \& STEIN, 1997) have received less support from empirical research (CARLINO \& DEFINA, 1998; OWYANG \& WALL, 2006).

\subsection{Regional Effects of Currency Unions in Non-OCA}

Differences in terms of sectoral GDP composition such as differing shares of interest rate sensitivity may thus lead to asymmetric responses to a common monetary policy not only across countries but also across regions within countries (MIHOV, 2001). The distinct perception of monetary policy measures becomes of particular relevance if a common monetary policy operates under non-OCA conditions. While the central bank will concentrate on addressing shocks that are common to the whole currency area (FORNI \& REICHLIN, 2001), regions within countries that are subject to national idiosyncratic shocks might be left with a less appropriate monetary policy compared to a national regime. Within countries, regions whose economies exhibit strong interest sensitivity will be disproportionally affected, e.g., by an inappropriately high interest rate (DORNBUSCH, FAVERO, \& GIAVAZZI, 1998).

However, the existence of costs associated with joining a currency area by no means implies that joining would not be feasible, as costs still need to be weighed against the benefits. A more open economy will reap higher gains from the reduction in transaction costs and exchange rate speculation and uncertainty. In contrast, the benefits of an independent monetary policy and exchange rate policy decline with the openness of an economy (KRUGMAN, 1990; MCKINNON, 1963). On the one hand, costs associated with the accommodation of shocks within a system of fixed exchange rates diminish as trade between economies increases. On the other hand, a greater degree of trade integration with partner 
countries makes it more likely that wages and prices are explicitly or implicitly indexed (KRUGMAN, 1990). As a result, the feasibility of joining a currency union essentially depends on the degree of economic integration (I) as well as economic homogeneity $(H)$ (e.g., in terms of business cycles) with respect to the partner countries. Given a certain level of integration $I^{*}$, a high degree of homogeneity would make a currency union desirable, while in the case of high heterogeneity the outside option would be feasible.

This basic scheme also proves a useful framework for the analysis of the sectoral and regional dimension of the cost-benefit problem. While the cost of joining the currency area for sector $n$ still depends on the overall level of the country's integration $I$ and heterogeneity $H$ (which are crucial for determining whether the overall economic development in the country is going to be affected positively or negatively) it will also depend on the degree to which a sector depends on foreign capital and thus its interest rate sensitivity $\left(i_{n}\right)$. At the same time, benefits from joining the currency union are also likely to vary across sectors. Again, a sector's benefit from joining the currency union will depend on the overall level of integration $l$, as its perspective depends on the overall evolution of the national economy. A sector's benefit will also depend on its own integration $I_{n}$ with the currency area, which may differ across sectors. A sector's net benefit $N_{n}$ thus depends on the overall level of integration $I$ and heterogeneity $H$ of the national economy, its own integration with the other economy $I_{n}$ and its interest sensitivity $i_{n^{\prime}}$ given that we deal with a non-OCA:

$N_{n}=g\left(I, H, I_{n}, i_{n}\right)$, with $\frac{\partial N_{n}}{\partial I_{n}}>0$ and $\frac{\partial N_{n}}{\partial i_{n}}<0$

A relatively high interest rate sensitivity of a sector under these assumptions leads to higher net costs when compared to an average sector. Net costs further increase if the sector has a particularly low integration with the other currency union member states' economies. In the opposite case of a sector that is not particularly interest rate sensitive (or additionally exhibits a high integration), there will be a net benefit of the sector relative to the rest of the economy. 
The utility of a rational voter in a referendum on joining a currency union thus depends on the economic structure of the region where she works. The probability that a perfectly informed voter will vote against the currency union $(V)$ is positively related to the net cost that the local industries will experience from the country's participation in the currency union. The probability will accordingly depend on the national level of economic integration and heterogeneity with respect to the rest of the currency area, the respective integration of the local industry $I_{1}$ and the industry's interest sensitivity $i$, as well as idiosyncratic preferences $(p)$ :

$V=f\left(I, H, I_{l}, i_{l}, p\right)$, with $\frac{\partial V_{n}}{\partial I_{n}}<0$ and $\frac{\partial V_{n}}{\partial i_{n}}<0$

As the integration and interest rate sensitivity of the local industry depend on the relative importance of local sectors $\left(s_{n}\right)$, so does the rational vote:

$V=f\left(I, H, \sum_{n} s_{n}, p\right)$

The impact of the relative importance of a sector $n$ on the decision of a rational voter in turn depends on the combination of relative currency area integration and interest rate sensitivity relative to other sectors. Clearly, the presence of sectors that exhibit relatively high interest rate sensitivity and low integration should raise the probability of a "no-vote," while the opposite is true for sectors with low interest rate sensitivity and high integration. Table 1 provides an inexhaustive classification of sectors that exhibit either relatively high interest sensitivity or integration, accompanied by the expected marginal impact on the probability of a "no-vote“.

As shown by CARLINO \& DEFINA $(1998,1999)$ among others, construction and manufacturing of consumer durables and capital goods tend to be among the most interest-sensitive industries. While services generally tend to be relatively independent of large amounts of foreign capital, a strong interest rate sensitivity has been revealed for wholesale and retail as well as transport and communication (GEORGOPOULOS, 2009). A difference between construction and the other interest-sensitive sectors, however, lies in the relatively low degree of integration 
with foreign economies. The presence of this sector, which occupies the upperright section in Table 1, should therefore increase voters' opposition to a currency union. The opposite should be true for services that do not exhibit a particularly high interest sensitivity (lower left section). Since the effects of interest sensitivity and integration run counter to each other for the upper-left section of Table 1 , there are no similarly clear-cut expectations, making the impact of the respective sectors an empirical issue.

Tab. 1 Sectoral Net Costs and Expected Impact on Regional Share of No-votes

\begin{tabular}{|c|c|c|c|c|}
\hline Integration & Above average & Net costs/ & Below average & Net costs/ \\
\hline Sensitivity & & $\begin{array}{l}\text { Exp. Impact on } \\
\text { No-votes }\end{array}$ & & $\begin{array}{l}\text { Exp. Impact on } \\
\text { No-votes }\end{array}$ \\
\hline $\begin{array}{c}\text { Above } \\
\text { average }\end{array}$ & $\begin{array}{l}\text { Manufacturing of } \\
\text { durables, wholesale } \\
\text { and retail trade, } \\
\text { transport and com- } \\
\text { munication }\end{array}$ & + & Construction & + \\
\hline
\end{tabular}

$\begin{gathered}\text { Below } \\ \text { average }\end{gathered}$ Other services
Notes: Own illustration on the basis of CARLINO \& DEFINA $(1998,1999)$ and GEORGOPOULOS
$(2009)$.

\subsection{The Euro-referenda in Denmark and Sweden}

On September 28, 2000 and September 14, 2003, Danish and Swedish voters were asked whether their countries should join the EMU in binding public referenda. There had not been any institutional requirements for the referenda, and in both countries, the government parties as well as the majority of opposing parties were supporting participation in the currency union. However, there was a surprisingly clear rate of rejection in both cases, which was interpreted as representing an increasing gap between the elite and the masses (MARCUSSEN \& ZØLNER, 2003; WIDFELDT, 2004).

In Sweden, 55.9 percent of the voters opted for the no-alternative, and the turnout was 82.6 percent. Voters followed the recommendation of the CALMFORS et al. (1997) Commission, which stated that Sweden should stay out of the EMU, maintain a floating exchange rate regime and reconsider the issue of joining in 
the near future. As Sweden was a late member of the EU, joining in 1994, its ties with the core might strengthen over time, making EMU membership more desirable later (BERGMAN, CHEUNG, \& HUTCHISON, 1997).

In the Danish case, the negative effects of a currency union were expected to be weaker, as the country is closer to the European core (e.g. BAYOUMI \& EICHENGREEN, 1993). Most important, as noted by the Danish Economic Council, the Danish economy would be little affected by participation in the EMU, as the Danish currency, the Krone, was already pegged to the Euro (LEDUC, 2003). However, a fixed or pegged exchange rate is never irrevocably fixed, and "exchange rates are made to be changed" (MÉLITZ, 1997, p. 361). Although the government and most opposition parties were in support of participation in the EMU, a clear majority of 53 percent of the electorate opted for the no-vote. Turnout was 88 percent.

The critical question for the purposes of this study is whether the assumption of perfect information holds for the voters in the referenda. There is a number of important points that support the notion of well-informed voters. First of all, the high turnout in both referenda reveals the strong public interest in the issue. In both countries, a long public debate about the consequences of monetary unification was providing the voters with all the pro and con arguments (HOBOLT, 2005; JONUNG, 2004; MARCUSSEN \& ZØLNER, 2003). The consequences of participation in the EMU and the consequences for the two countries were discussed in detail, especially in the Swedish case, where even foreign economists such as Robert Mundell, Andrew Rose and Joseph Stiglitz gave their views on the issue in the Swedish media (JONUNG, 2004). The fact that both governing and opposing parties supported the issue further ensured that voters' perceptions were not subject to a major bias due to political party affiliation. Not least, exit polls revealed that the issue of 'the interest rate determined in Sweden/Denmark' in particular was of major importance for the no-voters (DE VREESE \& SEMETKO, 2004). 


\section{Empirical Analysis}

\subsection{Empirical Strategy}

Ideally, an empirical test of equation (3) would be based on observations of the individual decisions and characteristics of voters, including their place of work. Such data, however, are not available, so the outcome of public referenda needs to be analyzed on the basis of data referring to more or less aggregated spatial units. It has become common praxis in the applied public choice literature to employ aggregated data (see e.g. DEACON \& SHAPIRO, 1975; KAHN \& MATSUSAKA, 1997; KLINE \& WICHELNS, 1994; SCHULZE \& URSPRUNG, 2000). Building on equation (3), we can assume that the probability $V_{j}$ of a voter $j$ voting "no" is related to countrywide effects of integration $(I)$ and heterogeneity $H$ with respect to the currency area that is captured by $\alpha$, the relevance of one or numerous sectors $n$ at the voter's place of work $\left(s_{n}\right)$ as well as a range of attributes $x_{m}$ that influence idiosyncratic preferences and other particularities of the voter's locality. The probability of a "no-vote" could be described with the cumulative logistic probability function:

$$
V_{j}=\frac{1}{1+\exp -\left(\alpha+\sum_{n} \beta_{n} s_{n j}+\sum_{m} \gamma_{m} x_{m j}\right)}
$$

where $\alpha, \beta_{n}$ and $\gamma_{m}$ are parameters. With this model, it follows that individuals will vote "no," provided that $\left(\alpha+\sum_{n} \beta_{n} s_{n j}+\sum_{m} \gamma_{m} x_{m j}\right)$ exceeds a certain threshold. If the behavior at the polls follows such a model, there is a linear relationship between the logarithm of the odds of a "yes" vote and the vector of the exogenous variables. Following the methodology of ecological inference, grouped statistical data can be used assuming that within constituencies individuals are completely identical with respect to the model attributes. ${ }^{1}$ Within the constraints of these assumptions, the probability $V_{j}$ that a representative voter will vote "no" can then be approximated through the percentage share of "no" votes $p c v_{i}$ of

An extensive discussion of the underlying assumptions of ecological inference can be found in SHIVELY (1969), KING (1997), or KING, ROSEN, \& TANNER (2004). 
constituency $i$. Equation (4) can thus be transferred into a regression equation of the following form:

$$
\log \left(\frac{p c v_{i}}{1-p c v_{i}}\right)=\alpha+\sum_{n} \beta_{n} s_{n i}+\sum_{m} \gamma_{m} x_{m i}+\varepsilon_{i}
$$

To correct for heteroskedasticity, variables are weighted with $w_{i}$, the inverse of the square root of the variance of the error term $\varepsilon_{i}$ (MADDALA, 1983; PINDYCK \& RUBINFELD, 1998):

$$
w_{i}=\frac{1}{\sqrt{\frac{o_{i}}{r_{i}\left(o_{i}-r_{i}\right)}}},
$$

where $o_{i}$ is the total number of votes and $r_{i}$ is the number of no-votes in constituency $i$.

The assumption of the homogeneity of individuals with respect to observable characteristics is obviously a rigid one. If, e.g., participation of voters in the referendum varies systematically with certain attributes, then the results will be biased (ecological fallacy). It is therefore more appropriate to interpret the results at the aggregated level to which the data refer. For the ease of quantitative interpretation, a number of studies have abstracted from equation (4) and directly investigated the voting outcome at the constituency level by means of OLS regression (BRUNNER \& SONSTELIE, 2003; COATES \& HUMPHREYS, 2006; DEHRING, DEPKEN, \& WARD, 2008).

$$
p c v_{i}=\alpha+\sum_{n} \beta_{n} s_{n i}+\sum_{m} \gamma_{m} x_{m i}+\omega_{i}
$$

While we show results corresponding to equation (5) mainly for the purpose of robustness checks, the bulk of our empirical analyses rely on the OLS approach (7). LM tests reveal a limited degree of spatial dependency in the data, which is possibly due to spatial measurement errors and omitted variables correlated across space. As the test score rejects a spatial lag model in favor of an error correction model, we employ maximum likelihood estimators to correct for spatial struc- 
tures in the error terms using the following relationship (ANSELIN, 2003; ANSELIN \& BERA, 1996; ANSELIN \& FLORAX, 1996): ${ }^{2}$

$\omega_{i}=\lambda W_{i j} \omega_{i}+\mu_{i}$

where $W$ is a contiguity weights matrix. ${ }^{3}$ The relative importance of a sector $n$ in region $i$ is captured by the respective proportion of the sector at total employment. The set of variables $x_{m}$ covers a set of socio-economic, demographic and political as well as spatial variables. We consider the regional rate of unemployment, as unemployed voters might be particularly receptive to the argument that an inappropriate monetary policy could have an adverse impact on the job market. If currencies are experience goods and a national currency has generally been associated with a long period of stability, then voters may exhibit preferences for the national system given that they are uncertain about the prospect of the new currency. ${ }^{4}$ Because experience with the national currency is naturally most significant among older people, we include the average age of the population to test and control for the experience effect. A stronger support for European integration within urban compared to rural areas has been reported in the literature, with the major exception being Denmark, where the opposite was reported for the past referenda (BUCH \& HANSEN, 2002) To capture the otherwise unobserved effect of urbanization, which might be related to the social or lifestyle-specific composition of city residents, we include a dummy variable (urban) that defines urban areas on the basis of a density of more than 150 residents per $\mathrm{km}^{2}$. Various alternative thresholds were tested, generally yielding similar results, but the chosen measure performed best in terms of the standard information criteria. It is intui-

2 Test scores are presented with the empirical results. An alternative form of spatial dependency would arise if the voting outcome directly depended on the results in neighboring constituicies, possibly due to cross-border interactions of voters. This form of dependency would be dealt with by spatial lag models.

3 All regions are treated as neighbors that are separated by a less-than-5-km edge distance to account for numerous minor fjords in the study area. If a region has no neighbor within a $5 \mathrm{~km}$ edge distance, than the nearest neighbor is assigned. Alternative weights matrices on the basis of various distance thresholds generally yield the same result.

4 The Danish People's Party's leader Pia Kjæresgaard expressed the rationale in a simplistic manner: 'You know what you've got. You don't know what you get.' (QVORTRUP, 2001) 
tive that supporters of parties opposing the EMU were more likely to vote against the EMU in a referendum if their affiliation resulted from general skepticism towards European integration. We therefore include the proportions of votes that the respective parties received in the preceding Folketing (in 1998) and Riksdag (in 2002) parliamentary elections (no-parties) as a control for political preferences. ${ }^{5}$ There is however, also the possibility of the support of no-parties and the probability of a no-vote in the referenda were jointly determined as the support of no-parties could be caused by variables considered in the analysis. The impact of the variables of interest under these circumstances would be subject to downward bias (proxy control problem). The exclusion of no-parties, slightly increases the magnitude of parameter estimates as expected, but leaves the qualitative pattern of results unaffected.

A number of additional spatial variables were generated within a GIS environment to account for effects related to the proximity to the European core and neighboring EU member states. Within the EU, border regions generally tend to disproportionally benefit from European integration (NIEBUHR, 2004). Therefore, dummy variables are generated denoting regions bordering another EU country or the Baltic Sea (border). As an indicator of remoteness we consider the distance to Frankfurt, Main, Germany, where the headquarters of the European central bank is located (distECB). The perceived costs and benefits of the monetary union may also vary between core regions and peripheral areas within countries. In the case of Sweden, we also consider the minimum road distance to one of the three major gateway cities: Stockholm (ferry terminal, airport), Gothenburg (ferry terminal) and Malmoe (Oeresund-bridge) (distgateway). Of various considered combinations of distance measures, this generally emerged as the most efficient. Similar settings were used for Denmark with centers consisting of the Danish capital Copenhagen, the Swedish city Malmö and the German cities Flensburg, Kiel or

In Denmark the 'no-parties' were found on the far ends of the political spectrum and accounted for 22 percent of the parliamentary seats. The 'no-parties' were: The Progress Party, the Socialist People's Party, the Christian People's Party, the Unity List and the Danish People's Party. In Sweden the Green Party, the Centre Party and the Left Party, accounting for 20 percent of the parliamentary seats, opposed to joining the EMU. 
Rostock (results were generally less comprehensive and will therefore not be reported). As the primary alternative for within-country centrality, however, a market potential (MP) in the HARRIS (1954) tradition is employed that is the distance $\left(\right.$ dist $_{i j}$ )-weighted aggregate of $G D P_{j}$ of regions $j$ neighboring region $i$. We use a standard internal distance measure dist $t_{i i}$ to account for heterogeneity in the size of regions (REDDING \& VENABLES, 2004).

$M P_{i}=\sum_{j} G D P_{j} \exp \left(-a\right.$ dist $\left._{i j}\right)$, where $_{\text {dist }} i \mathrm{i}=\frac{2}{3} \sqrt{\frac{\text { area }_{i}}{P i}}$.

Parameter $a$, which determines the degree to which neighboring regions are discounted on distance, is set to a value of 0.012 after evaluation of numerous alternatives based on the standard information criteria. This value is within the range of parameter estimates provided by AHLFELDT \& FEDDERSEN (2008), which were derived from the estimation of a European spatial wage-income relationship.

In small spatial units such as municipalities, cross commuting may lead to the sectoral composition at neighboring municipalities exhibiting an impact on the local voting outcome. As an alternative to the within-region fraction of total employment, we therefore propose the proportion of distance-weighted employment within a sector at distance-weighted total employment. The same internal distance measure applies as in (9). The spatial discount parameter $b$ is set to 0.1 , which is roughly in line with the work of AHLFELDT (2008), who estimates a commuting cost function to account for the employment opportunities in neighboring municipalities. This parameter value implies that only a small fraction of people commutes at distances larger than $50 \mathrm{~km}$; this seems to reflect well the situation in Sweden (ÖHMAN \& LINDGREN, 2003). The implicit decay functions according to parameters $a$ and $b$ are visualized in Figure $A 1$ in the appendix.

$s_{n i}=\frac{\sum_{j} e \text { emp }_{n j} \exp \left(-b \text { dist }_{i j}\right)}{\sum_{j} \text { emptotal }_{j} \exp \left(-b \text { dist }_{i j}\right)} \times 100$

While in the first instance we focus on the case of Sweden, where the alternative option to joining the currency union was flexible exchange rates, results are also compared to the case of Denmark. We further consider the 1994 referendum on 
the EU participation of Sweden, which implicitly was a referendum on the Euro perspective, given that the EU had agreed on the plans for a currency union in 1992. The empirical analyses rely on data at the level of municipalities, which is the highest detail for which the considered data are available.

\subsection{Data}

All data used in the empirical analyses were obtained from the national agencies for statistics, i.e., the Statbank Denmark and the Statistika centralbyrån of Sweden. Sweden is subdivided into 21 'Län' or counties, with these counties being subdivided into 290 municipalities. Denmark is subdivided into 15 counties $^{6}$ and 275 municipalities. Regarding the key variables of interest, for Sweden a broad range of sectorally disaggregated data on employment and output were available at the municipality level, including construction, the manufacturing of consumer durables and capital goods and various services, among others. Some of the NACE classifications that are of particular interest following table 1 are D25-33, the manufacturing of consumer durables and capital goods; F45, construction ; G-O, services (in particular, G50-52, wholesale and retailing; and 160-62 transport, storage and communications). For Denmark, however, access was generally more restricted. At the municipal level, data were grouped into 9 sectors including the construction sector (F45) and financial intermediation (J6). Wholesale and retailing, however, was only available, along with hospitality (G50-52 and H55). Data on transport, storage and communications were available at the 1-digit NACE level (16). No data were available for manufacturing of consumer durables and capital goods, as authorities claimed the respective data on industrial composition to be confidential. Another restriction of data refers to the GDP, which was only available at the county level. For the generation of market potential, we therefore approximate a municipality-level GDP on the basis of total employment at municipalities, assuming constant productivity within counties.

${ }^{6}$ Technically, there are only 14 'Amter' and the urban area of the capital Copenhagen. 
While conducting the analysis, a few outliers that showed large residuals had to be excluded. These were in both cases municipalities with low shares of 'novotes,' suggesting that the models cannot explain these low shares sufficiently. There is a high degree in spatial heterogeneity in the voting outcome, both in Denmark, where the share of "no-votes" varies between 29 and 75 percent, and in Sweden, where the respective share varies between 24 and 87 percent. $^{7}$ The spatial distribution of "no-votes" is visualized at the municipality level in Figure 2.

7 The respective ranges for counties are: 49 to 59 percent in Denmark and 44 to 78 percent in Sweden. 
Fig. 1 Spatial Distribution of "No-votes" in Sweden and Denmark

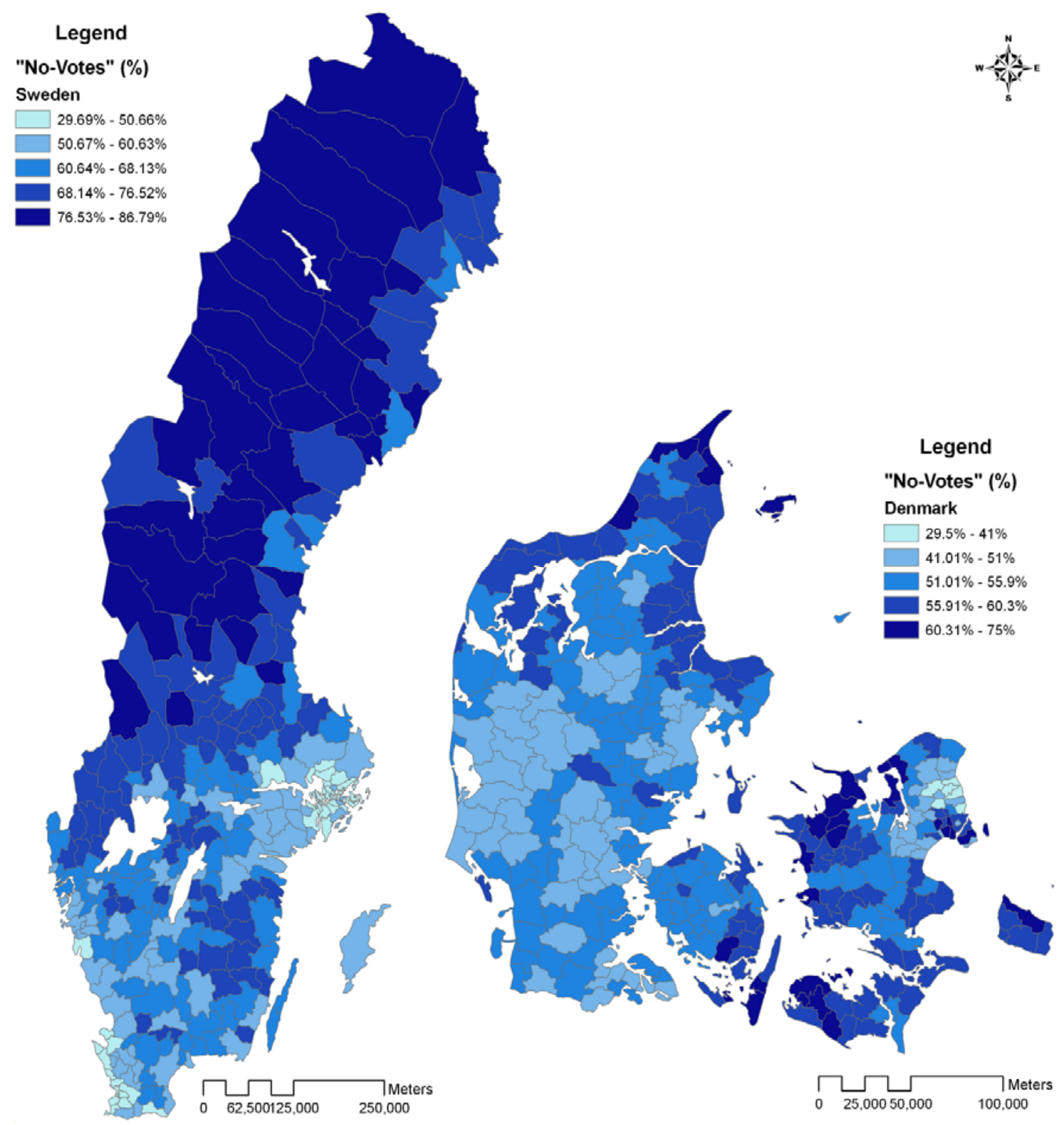

Notes: Own illustration. Figure is stylized to save space.

Particularly in Sweden, an evident spatial pattern becomes apparent at first glance. There is striking north-south heterogeneity and a notable reduction in the share of "no-votes" along the eastern border areas, in line with the propositions made on the role of borders and centrality. Similar patterns are, if visible at all, only visible to a much lesser degree in the case of Denmark. 


\subsection{Empirical Results}

\subsubsection{Baseline Results for Sweden}

The empirical results corresponding to our baseline specification (7) for the 2000 referendum in Sweden are presented in Table 2, column (1). The results confirm the pattern shown in Figure 1 in that voters living closer to the European core, within economic agglomerations and along the EU boundaries show relatively little opposition to EMU. The share of "no-votes" increased by 0.8 percentage points for every $100 \mathrm{~km}$ increase in distance from the ECB. Within border regions, the rate of rejection was more than 4 percentage points lower as compared to other regions. A similar result is found for urban areas relative to rural areas, where the respective differential amounts to about 5 percentage points. For any increase in the average age of the population in municipalities by one year, there is a corresponding increase of about 0.8 percentage points in the rate of rejection of the EMU, confirming the notion that currencies exhibit the characteristics of experience goods. While no significant relationship is revealed between the rate of unemployment and the rate of rejection, the presence of a larger fraction of voters supporting parties that oppose the EMU results in more "no-votes," as expected.

As discussed in section 2, the presence of a strong construction sector in a given region, all other attributes being equal, should increase the local net cost of participation in the EMU and therefore positively impact the share of "no-votes." The opposite is expected for services if the interest-sensitive sectors wholesale and retailing (G50-52) and transport and communications (160-62) are excluded. The empirical results match these expectations well. A 1 percentage point increase in the municipality share of employment within construction by leads to a conditional 0.165 percentage point increase in the share of "no-votes". In contrast, a similar increase in the share of interest-insensitive services sector is associated with a 0.15 percentage point reduction in the share of "no-votes".

As discussed in section 2, votes are collected at places of residence, which are not necessarily the same as places of work. The voting outcome in a given municipali- 
ty may therefore be driven by the sectoral distribution of employment within neighboring municipalities if voters commute across municipal boundaries. Therefore, in column 2, shares of employment refer to distance-weighted employment, including neighboring municipalities as defined in equation (10). The relevant coefficients, however, remain qualitatively unchanged, significant and of roughly the same magnitude. Apparently, commuting across municipality boundaries does not represent a source of major bias.

In both OLS regressions of model (1) and (2), the LM tests point to the presence of significant spatial dependency and the appropriateness of a spatial error correction model that corrects for a spatial structure in the error term as in equation (8). ${ }^{8}$ This form of spatial dependency is likely to be caused by spatial measurement error or unobserved variables that are correlated across space.

Correction for spatial dependency, however, does not change the qualitative implications for the two key sectors of interest. In all models, as expected, larger proportions of employment in construction increases opposition, while the opposite is true for the interest-insensitive services. The sectors for which no ex-ante expectations of voting behavior exist exhibit a less striking influence on the voting outcome. Manufacturing of consumer durables and capital goods on local opposition cannot be rejected to have no impact on the basis of any of Table 2 models. This is in line with (expected) relative positive and negative effects of the EMU cancelling each other out. Regarding the service sectors, we find significantly negative impact on no-votes for wholesale and retailing (Services G50-52) and transport, storage and communications (160-62) in models (1) and (4) and models (1) and (3), respectively. Generally, the pattern of results remains almost unchanged throughout models (1) to (4) with the exception of market potential, which is no longer statistically significant in column (3). The magnitude of coefficient point estimates is similar in the OLS and SAR model. If spatially weighted

8 LM statistics are LMerror : 16.84, Robust LMerror : 15.61, LMlag : 2.10, Robust LMlag : 0.87 for model (3) and LMerror : 13.80, Robust LMerror : 14.06, LMlag :0.02, Robust LMlag : 0.37 for model (4). 
employment variables are used (4), the lambda coefficient even becomes insignificant. Overall problems of spatial dependency are of relatively little concern.

Note that the pattern of results is approved if the impact of manufacturing of consumer durables and capital goods and interest-insensitive services is investigated at sub-sector level. Table A1 shows results corresponding to Table (1), column (1) type specifications where 14 sub-sectors are considered separately, in each case with the same set of non-sectoral control variables. With the exception of manufacturing of fabricated metal products (F28), which positively impacts the share of "no-votes," none of the considered manufacturing sub-sectors exhibits a significant impact. Similarly, all additional sub-sector services variables exhibit a negative and significant impact, with the only exception being community, social and personal services (O), which show no significant impact. 
Tab. 2 Baseline Results: Sweden

\begin{tabular}{|c|c|c|c|c|}
\hline & $\begin{array}{l}(1) \\
\text { OLS }\end{array}$ & $\begin{array}{l}\text { (2) } \\
\text { OLS }\end{array}$ & $\begin{array}{l}(3) \\
\text { SAR }\end{array}$ & $\begin{array}{l}(4) \\
\text { SAR }\end{array}$ \\
\hline $\begin{array}{l}\text { Distance to ECB } \\
\qquad(\mathrm{km})\end{array}$ & $\begin{array}{l}0.007^{* *} \\
(0.001)\end{array}$ & $\begin{array}{l}0.007^{* *} \\
(0.001)\end{array}$ & $\begin{array}{l}0.009^{* *} \\
(0.003)\end{array}$ & $\begin{array}{l}0.007^{* *} \\
-0.001\end{array}$ \\
\hline $\begin{array}{c}\text { Market Potential (MP) } \\
(10 \text { Mio SEK) }\end{array}$ & $\begin{array}{l}-1.78 \mathrm{e}-05^{* *} \\
(2.87 \mathrm{e}-06)\end{array}$ & $\begin{array}{l}-1.44 \mathrm{e}-05^{* *} \\
(3.19 \mathrm{e}-06)\end{array}$ & $\begin{array}{r}-8.41 e-06 \\
(8.22 e-06)\end{array}$ & $\begin{array}{l}-1.44 \mathrm{e}-05^{* * *} \\
(3.12 \mathrm{e}-06)\end{array}$ \\
\hline $\begin{array}{l}\text { Border } \\
\text { (dummy) }\end{array}$ & $\begin{array}{l}-4.304^{* *} \\
(0.697)\end{array}$ & $\begin{array}{l}-4.373^{* *} \\
(0.731)\end{array}$ & $\begin{array}{l}-3.119^{* *} \\
(0.911)\end{array}$ & $\begin{array}{l}-4.372^{* *} \\
(0.750)\end{array}$ \\
\hline $\begin{array}{l}\text { Urban } \\
\text { (dummy) }\end{array}$ & $\begin{array}{l}-5.021^{* *} \\
(1.369)\end{array}$ & $\begin{array}{l}-3.888^{* *} \\
(1.453)\end{array}$ & $\begin{array}{l}-5.678^{* *} \\
(1.721)\end{array}$ & $\begin{array}{l}-3.888^{* *} \\
(1.424)\end{array}$ \\
\hline $\begin{array}{l}\text { Average age } \\
\text { (years) }\end{array}$ & $\begin{array}{l}0.853^{* *} \\
(0.169)\end{array}$ & $\begin{array}{l}0.544^{* *} \\
(0.206)\end{array}$ & $\begin{array}{l}1.073^{* *} \\
(0.116)\end{array}$ & $\begin{array}{l}0.544^{*} \\
(0.219)\end{array}$ \\
\hline $\begin{array}{l}\text { Unemployment rate } \\
(\%)\end{array}$ & $\begin{array}{l}-0.023 \\
(0.183)\end{array}$ & $\begin{array}{c}0.001 \\
(0.187)\end{array}$ & $\begin{array}{l}0.187 \\
(0.177)\end{array}$ & $\begin{array}{l}0.001 \\
(0.181)\end{array}$ \\
\hline $\begin{array}{l}\text { No-Parties } \\
(\%)\end{array}$ & $\begin{array}{l}0.733^{* *} \\
(0.095)\end{array}$ & $\begin{array}{l}0.773^{* *} \\
(0.097)\end{array}$ & $\begin{array}{l}0.638^{* *} \\
(0.092)\end{array}$ & $\begin{array}{l}0.773^{* *} \\
(0.095)\end{array}$ \\
\hline $\begin{array}{l}\text { Construction } \\
(\%)\end{array}$ & $\begin{array}{l}0.162^{* *} \\
(0.061)\end{array}$ & $\begin{array}{c}0.266^{*} \\
(0.117)\end{array}$ & $\begin{array}{c}0.143^{*} \\
(0.062)\end{array}$ & $\begin{array}{c}0.266^{*} \\
(0.114)\end{array}$ \\
\hline $\begin{array}{c}\text { Manufact. Durables } \\
(\%)\end{array}$ & $\begin{array}{l}0.014 \\
(0.023)\end{array}$ & $\begin{array}{l}-0.030 \\
(0.038)\end{array}$ & $\begin{array}{l}0.030 \\
(0.023)\end{array}$ & $\begin{array}{l}-0.030 \\
(0.038)\end{array}$ \\
\hline $\begin{array}{l}\text { Services G50-52 } \\
\text { (\%) }\end{array}$ & $\begin{array}{l}-0.085^{*} \\
(0.046)\end{array}$ & $\begin{array}{l}0.024 \\
(0.061)\end{array}$ & $\begin{array}{l}0.030 \\
(0.044)\end{array}$ & $\begin{array}{c}0.024 \\
(0.063)\end{array}$ \\
\hline $\begin{array}{c}\text { Services 160-62 } \\
(\%)\end{array}$ & $\begin{array}{l}-0.054 \\
(0.057)\end{array}$ & $\begin{array}{c}0.074 \\
(0.112)\end{array}$ & $\begin{array}{l}-0.010 \\
(0.053)\end{array}$ & $\begin{array}{c}0.074 \\
(0.111)\end{array}$ \\
\hline $\begin{array}{l}\text { Remaining services } \\
(\%)\end{array}$ & $\begin{array}{l}-0.134^{* *} \\
(0.029)\end{array}$ & $\begin{array}{l}-0.223^{* *} \\
(0.055)\end{array}$ & $\begin{array}{l}-0.112^{* *} \\
(0.027)\end{array}$ & $\begin{array}{l}-0.223^{* *} \\
(0.053)\end{array}$ \\
\hline Constant & $\begin{array}{l}14.855^{*} \\
(7.442)\end{array}$ & $\begin{array}{l}29.627^{* *} \\
(8.894)\end{array}$ & $\begin{array}{c}0.003 \\
(0.422)\end{array}$ & $\begin{array}{l}29.609^{* *} \\
(10.238)\end{array}$ \\
\hline Lambda & & & $\begin{array}{l}0.134^{* * *} \\
(0.032)\end{array}$ & $\begin{array}{c}2.77 e-05 \\
(0.006)\end{array}$ \\
\hline Sector employment & unweighted & weighted & unweighted & weighted \\
\hline Observations & 288 & 288 & 288 & 288 \\
\hline (Pseudo) R-squared & 0.856 & 0.845 & 0.843 & 0.845 \\
\hline Mean VIF & 1.81 & 2.13 & 1.81 & 2.13 \\
\hline $\mathrm{AIC}$ & 1666.119 & 1687.002 & 1642.190 & 1691.002 \\
\hline
\end{tabular}

Notes: The endogenous variable is the share of "no-votes" in all models. The sector variables represent the share of sector employment at total employment within municipalities in (1) and (3) and the same for spatially weighted employment as in equation (10) in (2) and (4). The standard errors (in parentheses) are robust to heteroskedasticity in (1) and (2) and are corrected for spatial dependency in (3) and (4). ${ }^{*} /{ }^{* *} /{ }^{* * *}$ denote significance at the 10 / 5 / 1 \% level. 


\subsubsection{Robustness Checks for Sweden}

A number of alterations to models (1) and (2) of Table 2 are tested in Table 3 to evaluate the sensitivity of results. First, we re-estimate the specifications employing a binary choice model as described in equation (5) [columns (1) and (2)]. Qualitatively, results are very similar to Table 2, columns (1) and (2). The presence of interest-insensitive service sectors exerts a clearly negative impact on the share of "no-votes" revealing (expected) relative net benefits. Wholesale and retailing (Services G) and transport, storage and communications (Services I), again exhibit a negative impact, if any impact at all, but they are statistically insignificant in (2), when potential commuting is accounted for. The only considerable difference is that the construction sector relatively sharply fails to satisfy conventional significance criteria in model (2) (p-value 0.179). The qualitative pattern of results for non-sector control variables is exactly the same as in Table 2, (1) and (2).

In column (3), we consider the minimum distance to the three major gateway cities Stockholm (ferry terminal, airport), Gothenburg (ferry terminal) and Malmoe (Oeresund-bridge) (distgateway) as an alternative to the market potential measure. First, we find that there is a significant positive relationship between the distance to the centers and the share of "no-votes," which, again, points to larger opposition to the EMU within peripheral areas. Second, after considering various thresholds, the best model fit is achieved when restricting the distance impact to an area no larger than $440 \mathrm{~km}$ of road distance from these main centers. This is done by introducing a dummy variable denoting the respective area (440km from Maincenter) in addition to an interactive term of the dummy with a continuous minimum distance measure (Distance to Maincenter). According to the estimation results, the rate of no-votes was reduced by up to 11.3 percentage points in the vicinity of the centers. With every $100 \mathrm{~km}$ increase in distance, the rejection rate increases by about 2.7 percent so that after $440 \mathrm{~km}$, the net effect becomes close to zero. Note that the distance variable also seems to largely pick up the effect of centrality with respect to the European core, as all three Swedish main centers are in the south and the impact of distance to the ECB is rendered 
insignificant. The estimates for all other variables, however, remain remarkably stable.

The same holds if the 1994 referendum on the Swedish participation in the EU is considered instead of the 2000 referendum on participation in the EMU. This referendum was held in the aftermath of the 1992 Maastricht treaty, where EU members had agreed on the creation of a common currency area. The results are, again, roughly in line with Table 2, column (1). The most notable differences are a less pronounced effect of "urbanity" and a now significantly positive impact of the rate of unemployment. A possible explanation would be that while the majority of Swedish voters expected a net benefit from joining the EMU, the unemployed were more anxious about reduced welfare expenditures and public investment as a result of Sweden's becoming a net payer in the European regional transfer system. Note that sectoral employment data were not available for 1994, making it necessary to use the 2003 figures for the respective variables and to impose the assumption that the regional sectoral composition did not change significantly between 1994 and 2003.

Last, we use our set of explanatory variables to investigate the support for Euroskeptical parties in the 2002 federal Riksdag elections. Although we controlled for a potential effect of affiliation to parties that oppose the currency union in the previous models, it is interesting to see whether voters' decisions to support these parties in turn depend on the sectoral composition at their locality. While results for non-sectoral control variables generally exhibit a strong similarity with Table 2, column (1), the impact of sectoral variables is less pronounced. In particular, the presence of interest-insensitive services, which constantly reduces the rejection rate in the direct referendums related to the EU/EMU, does not exhibit any significant impact. 
Tab. 3 Robustness Checks: Sweden

\begin{tabular}{|c|c|c|c|c|c|}
\hline & $\begin{array}{l}(1) \\
(B C)\end{array}$ & $\begin{array}{l}(2) \\
(B C)\end{array}$ & $\begin{array}{l}\text { (3) } \\
\text { OLS }\end{array}$ & $\begin{array}{l}(4) \\
\text { OLS }\end{array}$ & $\begin{array}{c}(5) \\
\text { (OLS) }\end{array}$ \\
\hline Dep. Var.: Share (\%) of & No-votes & No-votes & No-votes & No-votes & No-Parties \\
\hline $\begin{array}{l}\text { Distance to ECB } \\
(\mathrm{km})\end{array}$ & $\begin{array}{l}-0.0004^{* *} \\
(5.28 \mathrm{e}-05)\end{array}$ & $\begin{array}{c}0.0004^{* *} \\
(5.91 \mathrm{e}-05)\end{array}$ & $\begin{array}{c}0.002 \\
(0.002)\end{array}$ & $\begin{array}{l}0.015^{* *} \\
(0.001)\end{array}$ & $\begin{array}{l}0.006^{* *} \\
(0.001)\end{array}$ \\
\hline $\begin{array}{c}\text { Market Potential (MP) } \\
(1 \text { Mio SEK) }\end{array}$ & $\begin{array}{c}-1.06 \mathrm{e}-06^{* *} \\
(1.21 \mathrm{e}-07)\end{array}$ & $\begin{array}{c}-9.62 \mathrm{e}-07^{* *} \\
(1.29 \mathrm{e}-07)\end{array}$ & & $\begin{array}{l}-3.22 \mathrm{e}-05 \\
(5.42 \mathrm{e}-06)\end{array}$ & $\begin{array}{l}-7.32 \mathrm{e}-06 \\
(1.95 \mathrm{e}-06)\end{array}$ \\
\hline $\begin{array}{l}\text { Border } \\
\text { (dummy) }\end{array}$ & $\begin{array}{l}-0.253^{* *} \\
(0.030)\end{array}$ & $\begin{array}{c}-0.250^{* *} \\
(0.031)\end{array}$ & $\begin{array}{l}-3.416^{* *} \\
(0.681)\end{array}$ & $\begin{array}{l}-4.794^{* *} \\
(0.815)\end{array}$ & $\begin{array}{l}-0.523 \\
(0.508)\end{array}$ \\
\hline $\begin{array}{l}\text { Urban } \\
\text { (dummy) }\end{array}$ & $\begin{array}{c}-0.218^{* *} \\
(0.055)\end{array}$ & $\begin{array}{c}-0.176^{* *} \\
(0.058)\end{array}$ & $\begin{array}{l}-5.667^{* *} \\
(1.311)\end{array}$ & $\begin{array}{l}-2.065 \\
(1.586)\end{array}$ & $\begin{array}{l}-2.641^{* *} \\
(0.668)\end{array}$ \\
\hline $\begin{array}{l}\text { Average age } \\
\text { (years) }\end{array}$ & $\begin{array}{l}0.034^{* *} \\
(0.007)\end{array}$ & $\begin{array}{l}0.023^{* *} \\
(0.008)\end{array}$ & $\begin{array}{l}0.828^{* *} \\
(0.174)\end{array}$ & $\begin{array}{l}0.792^{* *} \\
(0.187)\end{array}$ & $\begin{array}{l}0.299^{*} \\
(0.124)\end{array}$ \\
\hline $\begin{array}{l}\text { Unemployment rate } \\
(\%)\end{array}$ & $\begin{array}{c}(0.0002) \\
(0.006)\end{array}$ & $\begin{array}{l}0.000 \\
(0.006)\end{array}$ & $\begin{array}{c}0.229 \\
(0.192)\end{array}$ & $\begin{array}{l}0.343^{* *} \\
(0.107)\end{array}$ & $\begin{array}{l}-0.130 \\
(0.107)\end{array}$ \\
\hline $\begin{array}{l}\text { No-Parties } \\
(\%)\end{array}$ & $\begin{array}{l}0.030^{* *} \\
(0.004)\end{array}$ & $\begin{array}{l}0.032^{* *} \\
(0.004)\end{array}$ & $\begin{array}{l}0.734^{* *} \\
(0.087)\end{array}$ & $\begin{array}{l}0.588^{* *} \\
(0.088)\end{array}$ & \\
\hline $\begin{array}{l}\text { Construction } \\
(\%)\end{array}$ & $\begin{array}{l}0.006^{* *} \\
(0.003)\end{array}$ & $\begin{array}{c}0.007 \\
(0.005)\end{array}$ & $\begin{array}{l}0.121^{*} \\
(0.063)\end{array}$ & $\begin{array}{l}0.155^{*} \\
(0.074)\end{array}$ & $\begin{array}{l}0.101^{*} \\
(0.043)\end{array}$ \\
\hline $\begin{array}{c}\text { Services G50-52 } \\
\text { (\%) }\end{array}$ & $\begin{array}{l}-0.004^{*} \\
(0.002)\end{array}$ & $\begin{array}{c}0.001 \\
(0.003)\end{array}$ & $\begin{array}{l}-0.053 \\
(0.053)\end{array}$ & $\begin{array}{l}-0.139^{*} \\
(0.063)\end{array}$ & $\begin{array}{l}-0.058 \\
(0.038)\end{array}$ \\
\hline $\begin{array}{c}\text { Services } 160-62 \\
\text { (\%) }\end{array}$ & $\begin{array}{l}-0.004 \\
(0.003)\end{array}$ & $\begin{array}{l}-0.001 \\
(0.003)\end{array}$ & $\begin{array}{l}-0.044 \\
(0.060)\end{array}$ & $\begin{array}{l}-0.024 \\
(0.070)\end{array}$ & $\begin{array}{l}-0.071 \\
(0.047)\end{array}$ \\
\hline $\begin{array}{c}\text { Manufact. Durables } \\
(\%)\end{array}$ & $\begin{array}{l}-0.001 \\
(0.001)\end{array}$ & $\begin{array}{l}-0.003 \\
(0.002)\end{array}$ & $\begin{array}{l}-0.004 \\
(0.026)\end{array}$ & $\begin{array}{l}-0.008 \\
(0.032)\end{array}$ & $\begin{array}{l}-0.021 \\
(0.021)\end{array}$ \\
\hline $\begin{array}{l}\text { Remaining services } \\
(\%)\end{array}$ & $\begin{array}{l}-0.005^{* *} \\
(0.001)\end{array}$ & $\begin{array}{c}-0.008^{* *} \\
(0.002)\end{array}$ & $\begin{array}{l}-0.144^{* *} \\
(0.031)\end{array}$ & $\begin{array}{l}-0.063^{*} \\
(0.036)\end{array}$ & $\begin{array}{l}-0.029 \\
(0.023)\end{array}$ \\
\hline $\begin{array}{l}440 \mathrm{~km} \text { from Maincenter } \\
\text { (dummy) }\end{array}$ & & & $\begin{array}{c}-11.394^{* *} \\
(1.900)\end{array}$ & & \\
\hline $\begin{array}{l}\text { Distance to Maincenter } \\
\times 440 \mathrm{~km} \text { dummy }\end{array}$ & & & $\begin{array}{l}0.027^{* *} \\
(0.004)\end{array}$ & & \\
\hline Constant & $\begin{array}{c}-1.226^{* *} \\
(0.336) \\
\end{array}$ & $\begin{array}{l}-0.720^{*} \\
(0.376) \\
\end{array}$ & $\begin{array}{c}21.721^{* *} \\
(7.972) \\
\end{array}$ & $\begin{array}{l}-1.117 \\
(8.950) \\
\end{array}$ & $\begin{array}{c}1.997 \\
(5.394) \\
\end{array}$ \\
\hline Sector employment & $\begin{array}{c}\text { un- } \\
\text { weighted }\end{array}$ & weighted & $\begin{array}{c}\text { un- } \\
\text { weighted }\end{array}$ & $\begin{array}{c}\text { un- } \\
\text { weighted }\end{array}$ & $\begin{array}{c}\text { un- } \\
\text { weighted }\end{array}$ \\
\hline Referendum & 2000 & 2000 & 2000 & 1994 & 2000 \\
\hline Observations & 288 & 288 & 288 & 284 & 288 \\
\hline R-squared & 0.858 & 0.854 & 0.851 & 0.8127 & 0.526 \\
\hline Mean VIF & 1.81 & 2.13 & 2.43 & 1.67 & 1.72 \\
\hline $\mathrm{AIC}$ & -107.182 & -99.207 & 1678.268 & 1748.393 & 1499.140 \\
\hline
\end{tabular}

Notes: The sector variables represent the share of sector employment at total employment within municipalities in (1) and (3-5) and the same for spatially weighted employment as in equation (10) in (2). The standard errors (in parentheses) are robust to heteroskedasticity. As 1994 sectoral employment was not available, 2003 figures are used in their place. The smaller number of observations for the 1994 referendum is attributable to a lower number of municipalities in that year. ${ }^{*} /{ }^{* *} /{ }^{* * *}$ denote significance at the $10 / 5 /$ $1 \%$ level. 


\subsubsection{Results for Denmark}

Table 4 shows estimation results of the analysis of the 2000 Euro referendum in Denmark corresponding to selected specifications in Table 2 and 3. As discussed in section 3.2, data availability for Denmark is somewhat more restricted than in the case of Sweden. Therefore, we cannot investigate the impact of manufacturing of consumer durables and capital goods. Services GH5 therefore also include the hospitality sector, while services I include transport, storage and communications. Data, however, still allow for a reasonable approximation of the most interesting sectors: construction and the interest-insensitive remaining services. Comparing column (1) results to Table 2, column (1), a number of similarities as well as contradictions become evident. Similarly to the case of Sweden, opposition increases with distance to the European core, average age and affiliation to parties that oppose participation in the EMU. In contrast to the case of the 2003 referendum in Sweden, the rate of unemployment has a significantly positive impact on the rejection rate. Market potential, urbanity and proximity to the border even show a significant effect in the opposite direction, increasing the share of "no-votes". These observed selected asymmetric characteristics between Denmark and Sweden are in line with (BUCH \& HANSEN, 2002), who report opposite patterns of attitudes between urban and rural regions in Denmark and Sweden. Also, compared to findings obtained for Sweden, the impact of services $I$ is now positive, indicating that perceived relative cost outweighs benefits. However, both sectors for which clear expectations exist exhibit the expected pattern of increased opposition in the case of construction and reduced share of "no-votes" in the case of interest-insensitive remaining services. The discussed pattern of results is fairly robust to alteration of model specifications, i.e., potential commuting (2), spatial dependency (3), or the application of a binary choice model (4). ${ }^{9}$ Model (5) corresponds to model (5) in Table 3 and tests for whether the support for anti-Euro parties in the 1998 federal Folketing elections depends on the local

9 As in the case of Sweden, LM-test scores reject the spatial-lag model in favour of an errorcorrection model. LM statistics are LMerror : 29.24, Robust LMerror : 26.27, LMlag : 9.62, Robust LMlag : 6.66 . 
composition of industries. Even more clear, as in the case of Sweden, is that the impact of industry mix on opposition to the EMU is a phenomenon specific to a direct vote on participation in a common currency area and is not a general expression of Euro-skepticism as reflected by support for no-parties.

Tab. 4 Results for Denmark

\begin{tabular}{|c|c|c|c|c|c|}
\hline & $\begin{array}{l}\text { (1) } \\
\text { OLS }\end{array}$ & $\begin{array}{l}\text { (2) } \\
\text { OLS }\end{array}$ & $\begin{array}{c}(3) \\
(S A R)\end{array}$ & $\begin{array}{c}(4) \\
(B C)\end{array}$ & $\begin{array}{c}(5) \\
\text { (OLS) }\end{array}$ \\
\hline Dep. Var.: Share (\%) of & No-votes & No-votes & No-votes & No-votes & No-Parties \\
\hline $\begin{array}{l}\text { Distance to ECB } \\
\qquad(\mathrm{km})\end{array}$ & $\begin{array}{l}9.89 \mathrm{e}-06^{* *} \\
(2.79 \mathrm{e}-06)\end{array}$ & $\begin{array}{l}1.09 \mathrm{e}-05^{* *} \\
(3.46 \mathrm{e}-06)\end{array}$ & $\begin{array}{c}1.97 \mathrm{e}-05^{* * *} \\
(4.73 \mathrm{e}-06)\end{array}$ & $\begin{array}{l}3.90 \mathrm{e}-07^{* *} \\
(1.04 \mathrm{e}-07)\end{array}$ & $\begin{array}{l}1.29 \mathrm{e}-05^{* *} \\
(2.27 \mathrm{e}-06)\end{array}$ \\
\hline $\begin{array}{c}\text { Market Potential (MP) } \\
(1 \text { Mio DKK) }\end{array}$ & $\begin{array}{l}0.0001^{* *} \\
(2.39 \mathrm{e}-05)\end{array}$ & $\begin{array}{c}0.0001^{* *} \\
(4.24 \mathrm{e}-05)\end{array}$ & $\begin{array}{c}0.0001^{* *} \\
(3.44 \mathrm{e}-05)\end{array}$ & $\begin{array}{l}5.29 \mathrm{e}-06^{* *} \\
(1.02 \mathrm{e}-06)\end{array}$ & $\begin{array}{l}4.64 \mathrm{e}-05^{*} \\
(2.55 \mathrm{e}-05)\end{array}$ \\
\hline $\begin{array}{l}\text { Border } \\
\text { (dummy) }\end{array}$ & $\begin{array}{l}0.923^{* *} \\
(0.354)\end{array}$ & $\begin{array}{l}0.880^{*} \\
-0.448\end{array}$ & $\begin{array}{l}0.828^{*} \\
(0.490)\end{array}$ & $\begin{array}{l}0.043^{* *} \\
(0.015)\end{array}$ & $\begin{array}{c}0.157 \\
(0.338)\end{array}$ \\
\hline $\begin{array}{l}\text { Urban } \\
\text { (dummy) }\end{array}$ & $\begin{array}{l}1.923^{* *} \\
(0.578)\end{array}$ & $\begin{array}{l}(0.149) \\
(0.740)\end{array}$ & $\begin{array}{l}1.207^{*} \\
(0.534)\end{array}$ & $\begin{array}{l}0.071^{*} \\
(0.029)\end{array}$ & $\begin{array}{c}0.632 \\
(0.602)\end{array}$ \\
\hline $\begin{array}{l}\text { Average age } \\
\text { (years) }\end{array}$ & $\begin{array}{l}0.339^{* *} \\
(0.107)\end{array}$ & $\begin{array}{c}0.181 \\
(0.143)\end{array}$ & $\begin{array}{l}0.576^{* *} \\
(0.068)\end{array}$ & $\begin{array}{l}0.011^{*} \\
(0.004)\end{array}$ & $\begin{array}{c}0.007 \\
(0.111)\end{array}$ \\
\hline $\begin{array}{l}\text { Unemployment rate } \\
(\%)\end{array}$ & $\begin{array}{l}1.467^{* *} \\
(0.125)\end{array}$ & $\begin{array}{l}1.427^{* *} \\
(0.150)\end{array}$ & $\begin{array}{l}1.305^{* *} \\
(0.163)\end{array}$ & $\begin{array}{l}0.059^{* *} \\
(0.005)\end{array}$ & $\begin{array}{c}0.028 \\
(0.135)\end{array}$ \\
\hline $\begin{array}{l}\text { No-Parties } \\
(\%)\end{array}$ & $\begin{array}{l}0.444^{* *} \\
(0.071)\end{array}$ & $\begin{array}{l}0.450^{* *} \\
(0.078)\end{array}$ & $\begin{array}{l}0.419^{* *} \\
(0.079)\end{array}$ & $\begin{array}{l}0.017^{* *} \\
(0.003)\end{array}$ & \\
\hline $\begin{array}{l}\text { Construction } \\
(\%)\end{array}$ & $\begin{array}{l}0.710^{* *} \\
(0.132)\end{array}$ & $\begin{array}{l}1.393^{* *} \\
(0.299)\end{array}$ & $\begin{array}{l}0.444^{* *} \\
(0.150)\end{array}$ & $\begin{array}{l}0.030^{* *} \\
(0.005)\end{array}$ & $\begin{array}{l}-0.088 \\
(0.122)\end{array}$ \\
\hline $\begin{array}{c}\text { Services GH5 } \\
(\%)\end{array}$ & $\begin{array}{c}0.043 \\
(0.130)\end{array}$ & $\begin{array}{l}-0.372 \\
(0.372)\end{array}$ & $\begin{array}{c}0.107 \\
(0.130)\end{array}$ & $\begin{array}{l}-0.003 \\
(0.005)\end{array}$ & $\begin{array}{l}-0.09 \\
(0.123)\end{array}$ \\
\hline $\begin{array}{l}\text { Services } 16 \\
(\%)\end{array}$ & $\begin{array}{l}0.310^{* *} \\
(0.119)\end{array}$ & $\begin{array}{l}0.736^{*} \\
(0.286)\end{array}$ & $\begin{array}{l}0.284^{*} \\
(0.115)\end{array}$ & $\begin{array}{l}0.014^{* *} \\
(0.004)\end{array}$ & $\begin{array}{c}0.084 \\
(0.081)\end{array}$ \\
\hline $\begin{array}{l}\text { Remaining services } \\
(\%)\end{array}$ & $\begin{array}{c}-1.223^{* *} \\
(0.154)\end{array}$ & $\begin{array}{l}-0.720^{*} \\
(0.317)\end{array}$ & $\begin{array}{c}-1.525^{* *} \\
(0.202)\end{array}$ & $\begin{array}{l}-0.043^{* *} \\
(0.006)\end{array}$ & $\begin{array}{l}-0.031 \\
(0.146)\end{array}$ \\
\hline Constant & $\begin{array}{l}11.813^{*} \\
(5.192)\end{array}$ & $\begin{array}{l}14.745^{*} \\
(7.342)\end{array}$ & $\begin{array}{c}0.233 \\
(0.768)\end{array}$ & $\begin{array}{c}-1.368^{* *} \\
(0.190)\end{array}$ & $\begin{array}{l}8.808^{*} \\
(4.838)\end{array}$ \\
\hline Lambda & & & $\begin{array}{c}0.987^{* * *} \\
(0.027) \\
\end{array}$ & & \\
\hline Sector employment & unweighted & weighted & unweighted & unweighted & unweighted \\
\hline Observations & 271 & 271 & 271 & 271 & 271 \\
\hline (Pseudo) R-squared & 0.746 & 0.649 & 0.694 & 0.748 & 0.168 \\
\hline Mean VIF & 2.22 & 2.22 & 2.22 & 2.22 & 2.30 \\
\hline AIC & 1271.908 & 1360.912 & 1233.955 & -465.353 & 1239.084 \\
\hline
\end{tabular}

Notes: The sector variables represent the share of sector employment at total employment within municipalities in (1) and (4-5) and the same for spatially weighted employment as in equation (10) in (2). The standard errors (in parentheses) are robust to heteroskedasticity. ${ }^{*} /{ }^{* *} /{ }^{* * *}$ denote significance at the $10 / 5 / 1 \%$ level. 


\section{Conclusion}

This article approaches the anticipated costs and benefits of a common monetary policy on the basis of public referenda on participation in the EMU held in Denmark and Sweden. These results provide new evidence on the regional effects of a common monetary policy and support the notion that the industrial mix is a significant driving force behind the regionally heterogeneous transmission (CRONE, 2007). In contrast to previous studies that explore the regional dimension of a common monetary policy on the basis of VAR models (CARLINO \& DEFINA, 1998, 1999), our approach allows for evaluation of regional and sectoral net cost that also takes into account potential benefits of larger currency areas. Our analysis, furthermore, is conducted at the municipal level, which presents greater spatial detail than that offered in previous analyses. In line with theoretical expectations, we find that voters in regions with a high proportion of interest-sensitive sectors that exhibit a low international integration, such as construction, tend to oppose participation in currency unions. The opposite is true for non-interest-sensitive sectors with a relatively high integration, e.g., non-interest-sensitive services. These findings are in line with the hypothesis that rational voters will maximize utility by voting in a way such that economic prospects at their locality are maximized. While some regional attributes such as economic centrality, urbanization and proximity to EU borders exhibit distinct impacts within Denmark and Sweden, the impact of the sectors of interest is consistently estimated for both countries. The results are generally robust to spatial dependency, accounting for crossmunicipality commuting and employing OLS or binary choice approaches. In addition to the influence of the regional industry mix and distance from the European core, a large proportion of supporters of political parties that oppose the EMU and a high average age within municipalities emerge as factors that consistently increase opposition to the currency union. While the former supports the notion of a less appropriate common European monetary policy in the periphery, the latter is in line with the hypothesis of a (successful) currency representing an experience good. Apparently, an implicit risk premium is imposed on the new currency that increases with the level of experience with the old currency. While industry mixes can explain the regional voting outcome in the Euro-referenda as expected, 
they cannot (or do to a much lesser degree) explain the regional support for political parties opposing the new currency, suggesting that we are indeed observing a currency effect rather than a broader effect of Euro-skepticism. 


\section{Appendix}

Fig. A1 Spatial Weight Functions

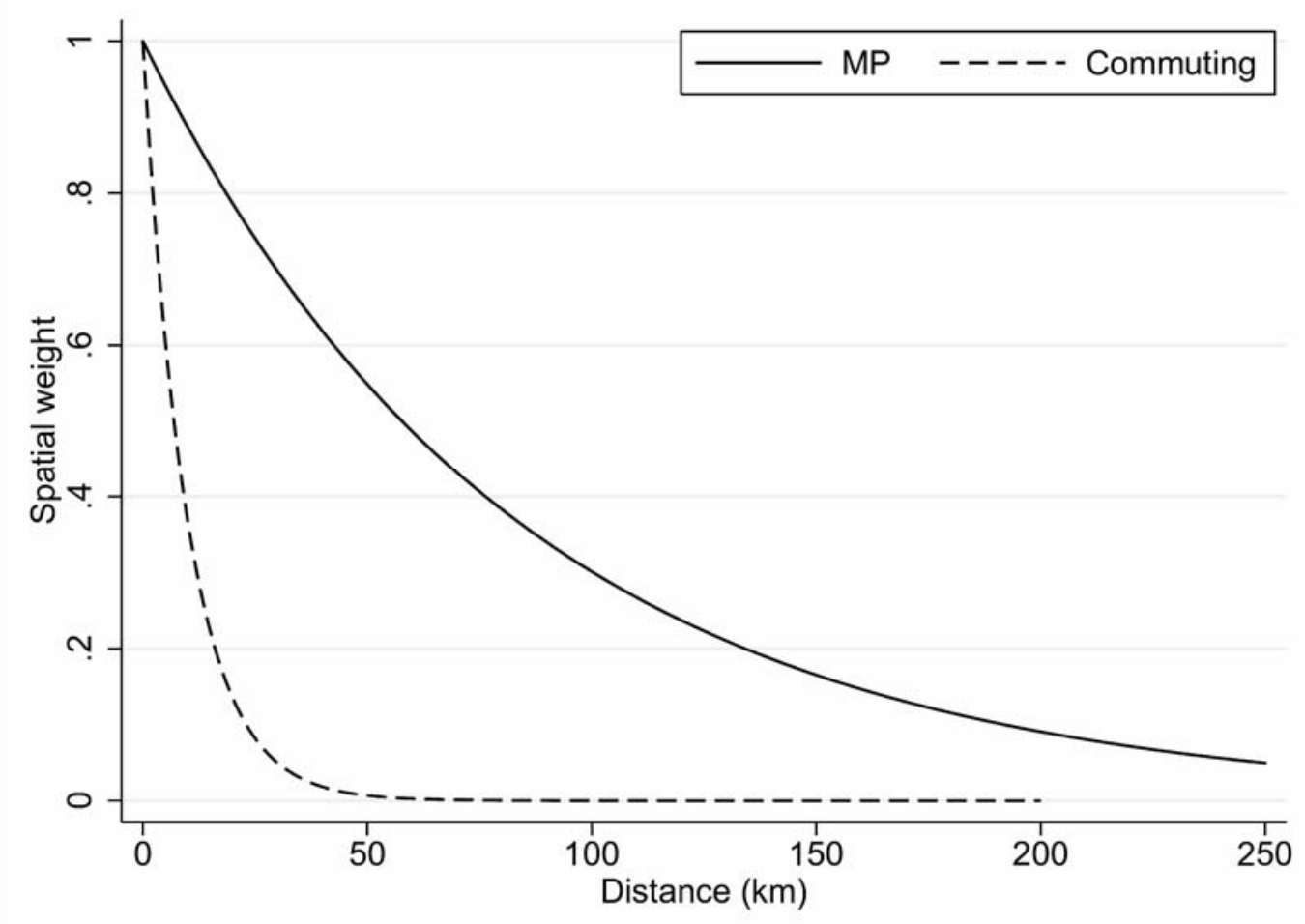

Source: Own illustration.

\section{Tab. A1 Results for Sub-Sectors: Sweden}

\begin{tabular}{clcc}
\hline \hline & Employees (\%) in & Coeff. & S.E. \\
\hline (1) & Manufacturing 25 (rubber and plastic products) & 0.092 & 0.076 \\
(2) & Manufacturing 26 (other non-metallic mineral products) & -0.027 & 0.106 \\
(3) & Manufacturing 27 (basic metals) & 0.016 & 0.050 \\
(4) & Manufacturing 28 (fabricated metal products) & $0.084^{*}$ & 0.044 \\
(5) & Manufacturing 29 (machinery and equipment) & -0.048 & 0.039 \\
(6) & Manufacturing 30 (office machinery and computers) & -5.666 & 11.870 \\
(7) & Manufacturing 31 (electrical machinery and apparatus) & 0.044 & 0.225 \\
(8) & Manufacturing 32 (radio, television and communication) & 0.57 & 0.794 \\
(9) & Manufacturing 33 (medical, precision, optical, watches) & 0.035 & 0.499 \\
(10) & Services H (hotels and restaurants) & $-0.168^{*}$ & 0.095 \\
(11) & Services K (real estate, renting and business activities) & $-0.110^{*}$ & 0.049 \\
(12) & Services M (education) & $-0.733^{* *}$ & 0.265 \\
(13) & Services N (health and social work) & $-0.265^{* *}$ & 0.092 \\
(14) & Services O (community, social and personal service) & -0.3 & 0.292 \\
\hline
\end{tabular}

Notes: The endogenous variable is share of "no-votes" in all models. The sector variables represent the share of sector employment at total employment within municipalities. All models include non-sector control variables as in model (1) of Table 1. The standard errors (S.E.) are robust to heteroskedasticity. ${ }^{*} /{ }^{* *} /{ }^{* * *}$ denote significance at the $10 / 5 /$ $1 \%$ level. 


\section{Literature}

AHLFELDT, G. M. (2008). If Alonso Was Right: Modeling Accessibility and Explaining the Residential Land Gradient. Revise \& Resubmit Journal of Regional Science.

AHLFELDT, G. M., \& FEDDERSEN, A. (2008). Determinants of Spatial Weights in Spatial Wage Equations: A Sensitivity Analysis. Hamburg Contemporary Economic Discussions, 22.

ANSELIN, L. (2003). Spatial Externalities. International Regional Science Review, 26(2), 147.

ANSELIN, L., \& BERA, A. K. (1996). Simple Diagnostic Tests for Spatial Dependence. Regional Science \& Urban Economics, 26(1), 77.

ANSELIN, L., \& FLORAX, R. J. G. M. (1996). Small Sample Properties of Tests for Spatial Dependency in Regression Models: Some Further Results. In L. Anselin, \& R. J. G. M. Florax (Eds.), New Directions in Spatial Econometrics (pp. 21-74). Berlin: Springer.

ARTIS, M. J., \& ZHANG, W. (2002). Membership of Emu: A Fuzzy Clustering Analysis of Alternative Criteria. Journal of Economic Integration, 17, 54-79.

BAYOUMI, T., \& EICHENGREEN, B. (1993). Shocking Aspects of European Monetary Integration. In F. Torres, \& F. Giavazzi (Eds.), Adjustment and Growth in the European Monetary Union. Cambridge: Cambridge University Press.

BAYOUMI, T., \& EICHENGREEN, B. (1996). Operationalizing the Theory of Optimum Currency Areas. CEPR Discussion Paper, No. 1484.

BERGMAN, M., CHEUNG, Y. W., \& HUTCHISON, M. M. (1997). Should the Nordic Countries Join a European Monetary Union? An Empirical Analysis. EPRU Working Paper Series, No. 1997-21.

BERNANKE, B. S., \& GERTLER, M. (1995). Inside the Black Box: The Credit Channel of Monetary Policy Transmission. Journal of Economic Perspectives, 9(4), 27-48.

BRUNNER, E., \& SONSTELIE, J. (2003). Homeowners, Property Values, and the Political Economy of the School Voucher. Journal of Urban Economics, 54(2), 239-257.

BUCH, R., \& HANSEN, K. M. (2002). The Danes and Europe: From Ec 1972 to Euro 2000 Elections, Referendums and Attitudes. Scandinavian Political Studies, 25(1), 1-26.

CALMFORS, L., FLAM, H., GOTTFRIES, N., HAALAND MATLARY, J., JERNECK, M., LINDAHL, R., NORDH BERNTSSON, C., RABINOWITZ, E., \& VREDIN, A. (1997). EMU - A Swedish Perspective. Dordrecht: Kluwer Academic Publishers.

CARLINO, G., \& DEFINA, R. (1998). The Differential Regional Effects of Monetary Policy. Review of Economics \& Statistics, 80(4), 572-587.

CARLINO, G., \& DEFINA, R. (1999). The Differential Regional Effects of Monetary Policy: Evidence from the U.S. States. Journal of Regional Science, 39(2), 339.

COATES, D., \& HUMPHREYS, B. R. (2006). Proximity Benefits and Voting on Stadium and Arena Subsidies. Journal of Urban Economics, 59(2), 285-299.

CRONE, T. M. (2007). A Pattern of Regional Differences in the Effects of Monetary Policy. Business Review (Federal Reserve Bank of Philadelphia), 9-19.

DE GRAUWE, P. (2007). Economics of Monetary Union (Vol. 7). Oxford: Oxford University Press. 
DE VREESE, C. H., \& SEMETKO, H. A. (2004). News Matters. Influences on the Vote in the Danish 2000. Euro Referendum Campaign. European Journal of Political Research, 43, 699-722.

DEACON, R., \& SHAPIRO, P. (1975). Private Preference for Collective Goods Revealed through Voting on Referenda. American Economic Review, 65(5), 943-955.

DEHRING, C. A., DEPKEN, C. A., \& WARD, M. R. (2008). A Direct Test of the Homevoter Hypothesis. Journal of Urban Economics, 64(1), 155-170.

DORNBUSCH, R. W., FAVERO, C. A., \& GIAVAZZI, F. (1998). The Immediate Challenges for the European Central Bank. Economic Policy, 13(26), 17-64.

DOW, S. C., \& RODRÍGUEZ-FUENTES, C. (2003). EMU and the Regional Impact of Monetary Policy. Regional Studies, 37(9), 969-980.

FATAS, A. (1997). Emu: Countries or Regions? Lessons from the EMS Experience. European Economic Review, 41, 743-751.

FELDSTEIN, M. (1997). The Political Economy of the European Economic and Monetary Union: Political Sources of an Economic Liability. Journal of Economic Perspectives, 11(4), 23-42.

FORNI, M., \& REICHLIN, L. (1997). National Policies and Local Economies: Europe and the United States. CEPR Discussion Paper, No. 1632.

FORNI, M., \& REICHLIN, L. (2001). Federal Policies and Local Economies: Europe and the Us. European Economic Review, 45, 109-134.

FRANKEL, J. A., \& ROSE, A. K. (1997). Is EMU More Justifiable Ex-Post Than Ex-Ante? European Economic Review, 41, 753-760.

GEORGOPOULOS, G. (2009). Measuring Regional Effects of Monetary Policy in Canada. Applied Economics, 41(16), 2093-2113.

HARRIS, C. D. (1954). The Market as a Factor in the Localization of Industry in the United States. Annals of the Association of American Geographers, 44(4), 315-348.

HOBOLT, S. B. (2005). The Impact of Political Information on Voting Behaviour in Eu Référendums. Journal of Elections, Public Opinion and Parties, 15(1), 85-109.

JANSSON, P. (1997). How Large Is the Risk of Asymmetric Shocks for Sweden? Swedish Economic Policy Review, 447-486.

JONUNG, L. (2004). The Political Economy of Monetary Unification: The Swedish Euro Referendum of 2003. Cato Journal, 24 Nos.1-2, 123-149.

KAHN, M. E., \& MATSUSAKA, J. G. (1997). Demand for Environmental Goods: Evidence from Voting Patterns on California Initiatives. The Journal of Law and Economics, 40(1), 137-173.

KASHYAP, A. K., \& STEIN, J. C. (1997). The Role of Banks in Monetary Policy: A Survey with Implications for the European Monetary Union. Federal Reserve Bank of Chicago, Economic Perspectives, September/October, 2-18.

KING, G. (1997). A Solution to the Ecological Inference Problem: Reconstructing Individual Behavior from Aggregate Data. Princeton, NJ: Princeton University Press.

KING, G., ROSEN, O., \& TANNER, M. A. (2004). Ecological Inference: New Methodological Strategies. Cambridge: Cambridge University Press. 
KLINE, J., \& WICHELNS, D. (1994). Using Referendum Data to Characterize Public Support for Purchasing Development Rights to Farmland. Land Economics, 70(2), 223-233.

KOUPARITSAS, M. A. (1999). Is the Emu a Viable Common Currency Area? A Var Analysis of Regional Business Cycles. Federal Reserve Bank of Chicago, Economic Perspectives, 23, 2-20.

KRUGMAN, P. R. (1990). Policy Problems of a Monetary Union. In P. De Grauwe, \& L. Papademos (Eds.), The European Monetary System in the 1990s (pp. 48-64). London/New York: Longman.

LEDUC, L. (2003). The Politics of Direct Democracy. Referendums in Global Perspective. Plymouth: Broadview Press.

MADDALA, G. S. (1983). Limited-Dependent and Qualitative Variables in Econometrics. Cambridge: Cambridge University Press.

MARCUSSEN, M., \& Z $\varnothing$ LNER, M. (2003). Monetarism and the Masses: Denmark and Economic Integration in Europe. Cooperation and Conflict, 39(2), 101-123.

MCKINNON, R. I. (1963). Optimum Currency Areas. American Economic Review, 53, 717725.

MÉLITZ, J. (1997). The Evidence About the Costs and Benefits of EMU. Swedish Economic Policy Review, 4, 359-410.

MIHOV, I. (2001). Monetary Policy Implementation and Transmission in the European Monetary Union. Economic Policy, 16(33), 371-406.

MONGELLI, F. P. (2002). 'New' Views on the Optimum Currency Area Theory: What is EMU Telling us? European Central Bank Working Paper Series, Nr. 138.

MUNDELL, R. A. (1961). A Theory of Optimum Currency Areas. American Economic Review, 51, 657-665.

NIEBUHR, A. (2004). Spatial Effects of European Integration: Do Border Regions Benefit above Average? HWWA Discussion Paper No. 307, Hamburg.

OBSTFELD, M., \& PERI, G. (1998). Regional Nonadjustment and Fiscal Policy: Lessons for Emu Economic Policy, 13(26), 207-295.

ÖHMAN, M., \& LINDGREN, U. (2003). Who Is the Long- Distance Commuter? Patterns and Driving Forces in Sweden. Cybergeo: European Journal of Geography. Retrieved September 5, 2009, from http://www.cybergeo.eu/index4118.html

OWYANG, M., \& WALL, H. J. (2006). Regional Vars and the Channels of Monetary Policy. Federal Reserve Bank of St. Louis Working Paper No. 2006-002A.

PINDYCK, R. S., \& RUBINFELD, D. L. (1998). Econometric Models and Economic Forecasts. Boston: Irwin/McGraw-Hill.

QVORTRUP, M. H. (2001). How to Lose a Referendum: The Danish Plebiscite on the Euro. The Political Quaterly, 72(2), 190-196.

REDDING, S. J., \& VENABLES, A. J. (2004). Economic Geography and International Inequality. Journal of International Economics, 62(1), 53-82.

SACHS, J., \& SALA-I-MARTIN, X. (1992). Fiscal Federalism and Optimum Currency Areas: Evidence for Europe from the United States. In M. B. Canzoneri, V. Grilli, \& P. R. Masson (Eds.), Establishing a Central Bank: Issues in Europe and Lessons from the U.S. Cambridge Cambridge University Press. 
SCHULZE, G. G., \& URSPRUNG, H. W. (2000). La Donna e Mobile -- or is She? Voter Preferences and Public Support for the Performing Arts. Public Choice, 102(1/2), 131-149.

SHIVELY, W. P. (1969). 'Ecological' Inference: The Use of Aggregate Data to Study Individuals. American Political Science Review, 63(4), 1183-1196.

WIDFELDT, A. (2004). Elite Collusion and Public Defiance: Sweden's Euro Referendum in 2003. West European Politics, 27(3), 503-517. 


\section{Hamburg Contemporary Economic Discussions}

(Download: http://www.uni-hamburg.de/economicpolicy/discussions.html)

01/2005 FEDDERSEN, A. / MAENNIG, W.: Trends in Competitive Balance: Is there Evidence for Growing Imbalance in Professional Sport Leagues?, January 2005.

02/2005 SIEVERS, T.: Information-driven Clustering - An Alternative to the Knowledge Spillover Story, February 2005.

03/2005 SIEVERS, T.: A Vector-based Approach to Modeling Knowledge in Economics, February 2005.

04/2005 BUETTNER, N. / MAENNIG, W. / MENSSEN, M.: Zur Ableitung einfacher Multiplikatoren für die Planung von Infrastrukturkosten anhand der Aufwendungen für Sportstätten - eine Untersuchung anhand der Fußball-WM 2006, May 2005.

01/2006 FEDDERSEN, A.: Economic Consequences of the UEFA Champions League for National Championships - The Case of Germany, May 2006.

02/2006 FEDDERSEN, A.: Measuring Between-season Competitive Balance with Markov Chains, July 2006.

03/2006 FEDDERSEN, A. / VÖPEL, H.: Staatliche Hilfen für Profifußballclubs in finanziellen Notlagen? - Die Kommunen im Konflikt zwischen Imageeffekten und Moral-Hazard-Problemen, September 2006.

04/2006 MAENNIG, W. / SCHWARTHOFF, F.: Stadium Architecture and Regional Economic Development: International Experience and the Plans of Durban, October 2006. 


\section{Hamburg Contemporary Economic Discussions}

(Download: http://www.uni-hamburg.de/economicpolicy/discussions.html)

01

02

03

04

05

06

07

08

O9

10

11

12

13

AHLFELDT, G. / MAENNIG, W.: The Role of Architecture on Urban Revitalization: The Case of "Olympic Arenas" in Berlin-Prenzlauer Berg, 2007.

FEDDERSEN, A. / MAENNIG, W. / ZIMMERMANN, P.: How to Win the Olympic Games - The Empirics of Key Success Factors of Olympic Bids, 2007.

AHLFELDT, G. / MAENNIG, W.: The Impact of Sports Arenas on Land Values: Evidence from Berlin, 2007.

DU PLESSIS, S. I MAENNIG, W.: World Cup 2010: South African Economic Perspectives and Policy Challenges Informed by the Experience of Germany 2006, 2007.

HEYNE, M. / MAENNIG, W. / SUESSMUTH, B.: Mega-sporting Events as Experience Goods, 2007.

DUST, L. / MAENNIG, W.: Shrinking and Growing Metropolitan Areas - Asymmetric Real Estate Price Reactions? The Case of German Single-family Houses, 2007.

JASMAND, S. I MAENNIG, W.: Regional Income and Employment Effects of the 1972 Munich Olympic Summer Games, 2007.

HAGN, F. / MAENNIG W.: Labour Market Effects of the 2006 Soccer World Cup in Germany, 2007.

HAGN, F. I MAENNIG, W.: Employment Effects of the World Cup 1974 in Germany.

MAENNIG, W.: One Year Later: A Re-appraisal of the Economics of the 2006 Soccer World Cup, 2007.

AHLFELDT, G., MAENNIG, W.: Assessing External Effects of City Airports: Land Values in Berlin, 2007.

AHLFELDT, G.: If Alonso was Right: Accessibility as Determinant for Attractiveness of Urban Location, 2007.

AHLFELDT, G.: A New Central Station for a Unified City: Predicting Impact on Property Prices for Urban Railway Network Extension, 2007. 


\section{Hamburg Contemporary Economic Discussions}

(Download: http://www.uni-hamburg.de/economicpolicy/discussions.html)

FEDDERSEN, A. / MAENNIG, W.: Arenas vs. Multifunctional Stadia Which Do Spectators Prefer?, 2007.

AHLFELDT, G. / FEDDERSEN, A.: Geography of a Sports Metropolis, 2007.

FEDDERSEN, A. / GRÖTZINGER, A. / MAENNIG, W.: New Stadia and Regional Economic Development - Evidence from FIFA World Cup 2006 Stadia, 2008.

AHLFELDT, G. / MAENNIG, W.: Monumental Protection: Internal and External Price Effects, 2008.

MAENNIG, W. / PORSCHE, M.: The Feel-good Effect at Mega Sport Events - Recommendations for Public and Private Administration Informed by the Experience of the FIFA World Cup 2006, 2008.

AHLFELDT, G.: The Train has Left the Station: Real Estate Price Effects of Mainline Realignment in Berlin, 2008.

MAENNIG, W. / WELLBROCK, C.-M.: Sozio-ökonomische Schätzungen Olympischer Medaillengewinne: Analyse-, Prognose- und Benchmarkmöglichkeiten, 2008.

MAENNIG, W. / ALLERMS, S.: South Africa 2010: Economic Scope and Limits, 2008.

AHLFELDT, G. / FEDDERSEN, A.: Determinants of Spatial Weights in Spatial Wage Equations: A Sensitivity Analysis, 2008.

AHLFELDT, G. / WENDLAND, N.: Fifty Years of Urban Accessibility: The Impact of Urban Railway Network on the Land Gradient in Industrializing Berlin, 2008.

AHLFELDT, G. / FRANKE, B. / MAENNIG, W.: Terrorism and the Regional and Religious Risk Perception of Foreigners: The Case of German Tourists, 2009.

FEDDERSEN, A. / MAENNIG, W.: Wage and Employment Effects of the Olympic Games in Atlanta 1996 Reconsidered, 2009.

AHLFELDT, G. I MAENNIG, W.: Impact of Non-Smoking Ordinances on Hospitality Revenues: The Case of Germany, 2009. 

On the Relation Between Income Inequality and Happiness: Do Fairness Perceptions Matter?, 2009. sectoral effects of a common monetary policy: evidence from Euro Referenda in Denmark and Sweden, 2009. 


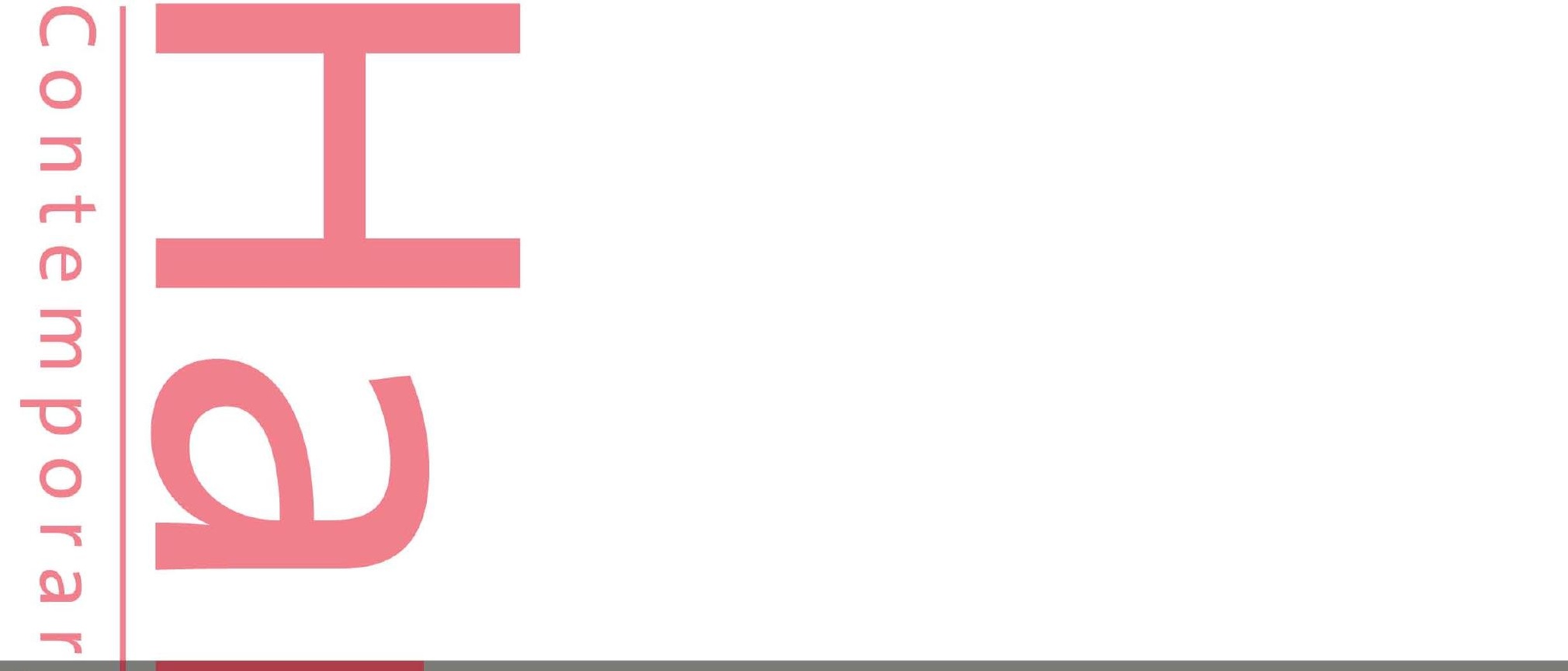

ISSN $1865-2441$ (PRINT) ISSN 1865-7133 (ONLINE)

ISBN 978-3-940369-70-3 (PRINT) ISBN 978-3-940369-71-o (ONLINE) 